
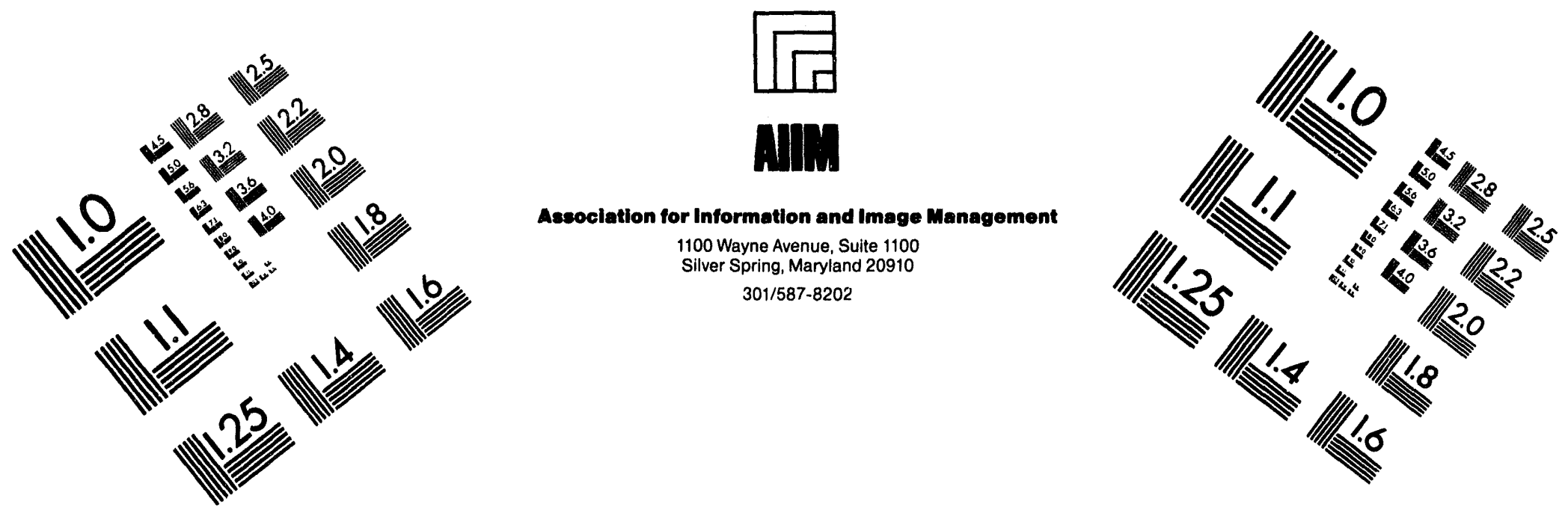

\title{
Centimeter
}

$\begin{array}{llllllllllllllll}1 & 2 & 3 & 4 & 5 & 6 & 7 & 8 & 9 & 10 & 11 & 12 & 13 & 14 & 15 & \mathrm{~mm}\end{array}$

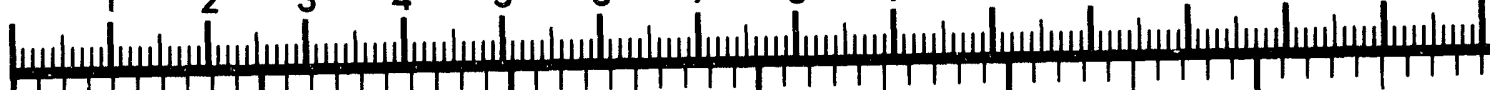

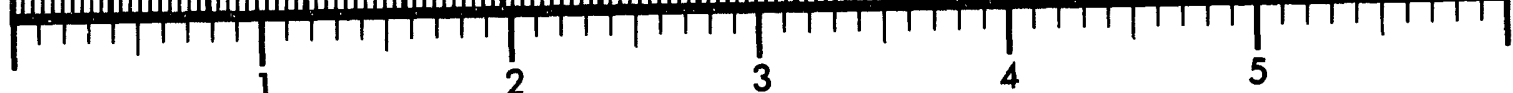
Inches

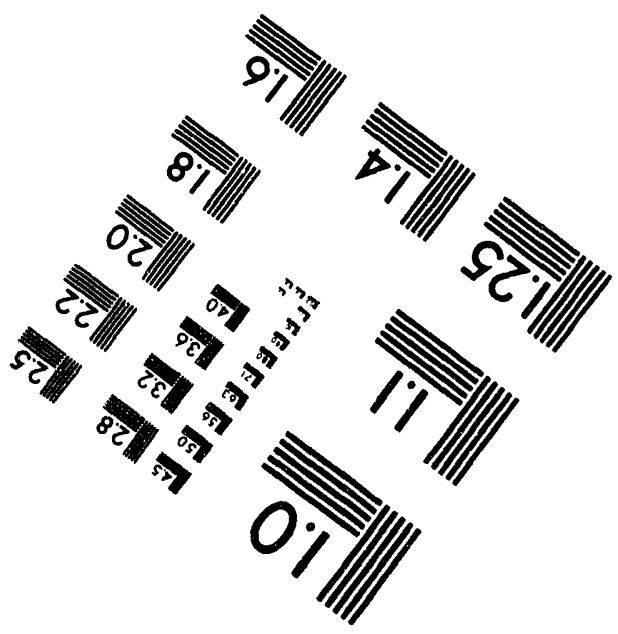

MANUFACTURED TO AIIM STANDARDS BY APPLIED IMAGE, INC.

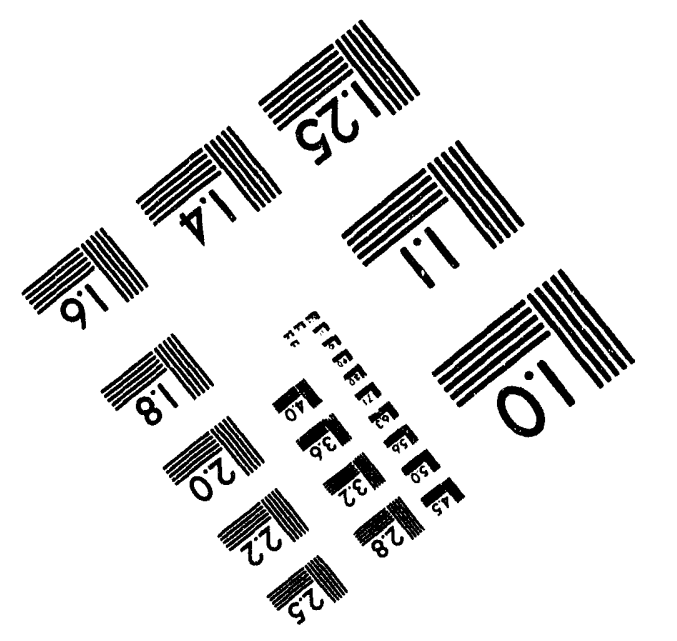



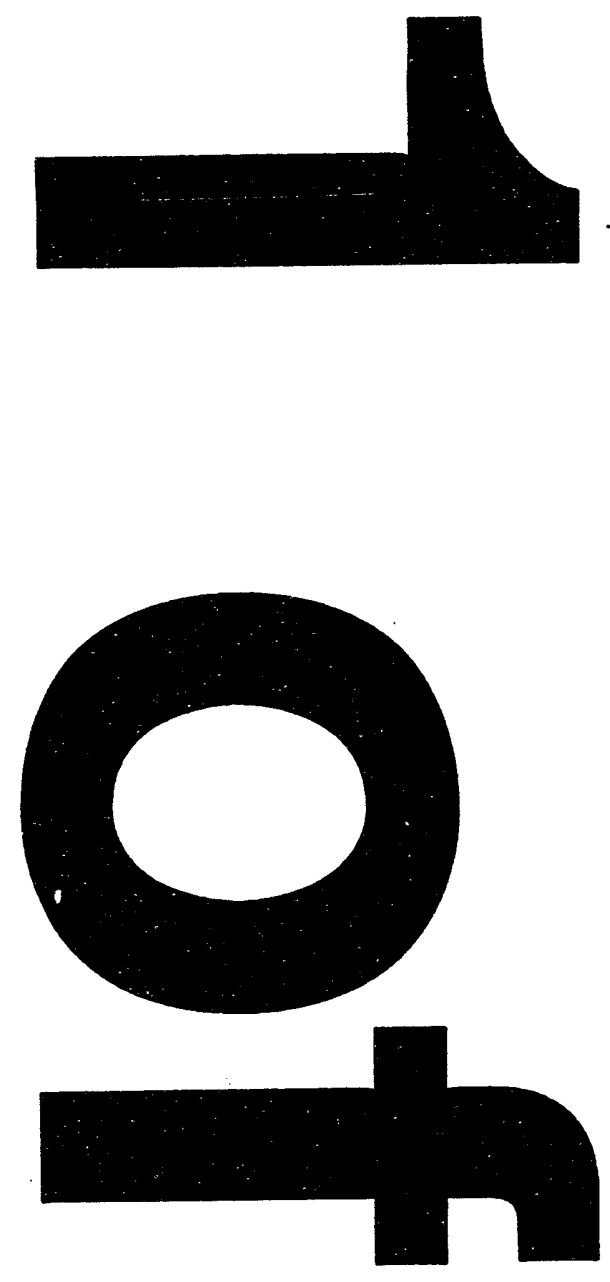

is

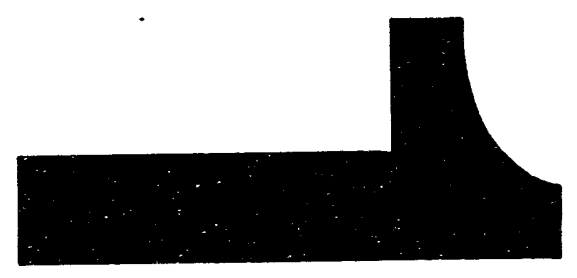




\title{
PACKAGING- AND TRANSPORTATION-RELATED OCCURRENCE REPORTS
}

\section{JANUARY-MARCH 1994}

\author{
Miriam J. Welch \\ Leonard S. Dickerson \\ Susan D. Jennings
}

June 1994

Prepared for the

Office for Environment, Safety and Health

HA 0109

Prepared by the

OAK RIDGE NATIONAL LABORATORY

Oak Ridge, Tennessee 37831-6285

managed by

MARTIN MARIETTA ENERGY SYSTEMS, INC.

for the

U. S. DEPARTMENT OF ENERGY

under contract DE-AC05-840R21400 
This report has been reproduced directly from the best available copy.

Available to DOE and DOE contractors from the Office of Scientific and Technical Information, P.O. Box 62, Oak Ridge, TN 37831; prices available from (615) 576-8401, FTS 626-8401.

Available to the public from the National Technical Information Service, U.S. Department of Commerce, 5285 Port Royal Rd., Springfield, VA 22161.

\section{DISCLAMMER}

This report was prepared as an scocunt of work sponsored by an agency of the United States Government. Neither the United States Government nor any agency thereof, nor any of their employees, makes any warranty, express or implied, or assumes any legal information, apparatus, product or process disclosed, or represents that its use would not infringe privately owned rights. References herein to any specific commencial product, process, or service by trade name, trademark, manufacturer, or otherwise, does not necessarily constitute or imply its endorsement, recommendation, or favoring by the United States Government or any agency thereof. The views and opinions of the authors expressed herein do not necessarily state or reflect those of the United States Government or any agency thereof. 
IABLE OF CONTENTS

Page

LIST OF FIGURES $\ldots \ldots \ldots \ldots \ldots \ldots \ldots \ldots \ldots$

LIST OF TABLES $\ldots \ldots \ldots \ldots \ldots \ldots$. . . . . . . . . . . . . . . . .

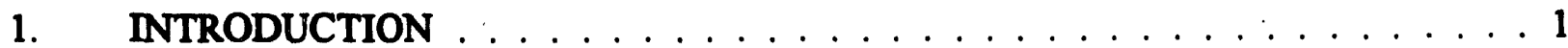

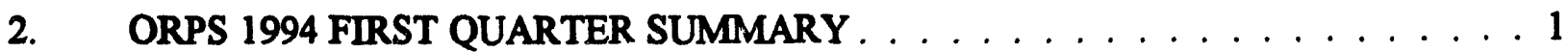

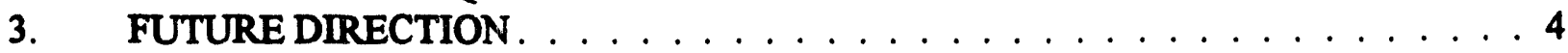


LIST OF FIGURES

Page

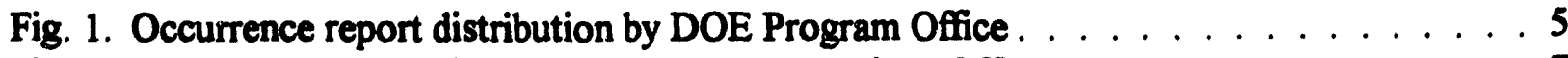

Fig. 2. Occurrence report distribution by DOE Operations Office. . . . . . . . . . . . 7

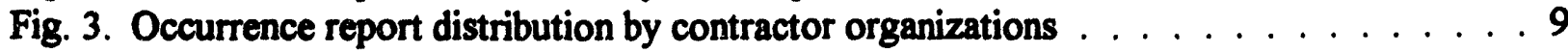

Fig. 4. Nature of Occurrence . . . . . . . . . . . . . . . . . . . . . . . . . . .13 
vii

\section{LIST OF TABLES}

Page

Table 1. Occurrence report distribution by DOE Program Office . . . . . . . . . . . . 5

Table 2. Occurrence report distribution by DOE Operations Office . . . . . . . . . . . . 6

Table 3. Occurrence report distribution by contractor organizations . . . . . . . . . . 8

Table 4. Occurrence report distribution by nature of occurrences . . . . . . . . . . . . . . 10

Table $5 . \quad$ Occurrences reported in Weekly Reports for the first quarter $1994 \ldots$. . . . . . 14 


\section{INTRODUCTION}

The Oak Ridge National Laboratory (ORNL) Packaging and Transportation Safety Program (PATS), which is sponsored by the U.S. Department of Energy (DOE) Office of Environment, Safety and Health Transportation and Packaging Safety Division, EH-332, has been charged with the responsibility of retrieving reports and information pertaining to transportation or packaging incidents or accidents from the Occurrence Reporting and Processing System (ORPS). These selected reports are being analyzed for trends, impact on EH-332 policies and concerns, and lessons learned concerning transportation and packaging safety. This task is desizned not only to keep EH-332 aware of what is occurring on DOE sites and potential transportation and packaging problems that may need attention, but also it is intended to allow future dissemination of lessons learned to the Operations Offices and subsequently to management and operating contractors.

This report, which covers the first quarter of 1994, includes the weekly tabular reports OR-94-1 through OR-9413, which were submitted to EH-332 for its information and use. Thirteen reports containing 43 selected occurrences were transmitted during this quarter.

\section{ORPS 1994 FIRST QUARTER SUMMARY}

DOE 5000.3B categorizes cocurrence reports (ORs) into three types: emergency, unusual, and off-normal. For transportation, DOE 5000.3B defines these three categories as the following:

1. Emengency is an offsite transportation event involving the release of a reportable quantity of hazardous substance (per 49 CFR. 171.8).

2. Unusual is an offsite transportation event involving the release of hazardous material in a quantity greater than limited quantities (or any release of radioactive material) or any shipment of radioactive material or hazardous waste that arrives at its destination (1) with a nonreconcilable shipping paper discrepancy or unaccounted-for package related to material quantity or (2) with radiation or contamination levels in excess of U.S. Department of Transportation (DOT) allowable limits. Violations of Federal Motor Carrier Safety Regulations or Federal Aviation Administration regulations involving a release of hazardous material are also included. Onsite "unusual occurrences" are defined similarly for releases.

3. Off-normal is defined as an offsite event involving a release of hazardous material other than radioactive that does not exceed a limited quantity. Violations of marking, labeling, placarding, routing, or separation/segregation of materials are included in its definition as well as is any transportation event involving departmental property resulting in vehicular or aircraft damage of more than $\$ 5,000$ (or total losses). Onsite "off-normal" events are defined as the same.

Of the 43 selected occurrences 4 were categorized as unusual. These occurrences are briefly detailed below.

1. On March 14, 1994, the Ames Laboratory in lowa reported a notice of noncompliance from the State of Temessee. Specifically, it appears that Ames Laboratory had shipped radioactive waste to Scientific Ecology Group without the authorization of a Tennessee license for delivery. A response was requested to describe the actions that will be required to bring Ames Laboratory activities into full compliance and that will avoid further noncompliance. At issue is whether DOE prime contractors are exempt from Tennessee requirements relating to transportation from government-owned sites.

[CH--AMES-AMES-1994-0002] 
2. On February 14, 1994, the Naval Petroleum Reserves of California reported a spill of about 120 bbl of crude oil and $180 \mathrm{bbl}$ of produced water. This spill occurred when a subcontractor vacuum-truck driver enoneousty dumped the liquids recovered from a previous spill at the $10 \mathrm{G}$ disposal facility, which is not designed for crude oil. The liquids ran off the surface into a sump and were contained there. Cleanup is continuing, and it is estimated that $90 \%$ of the crude oil will be recovered. Additional water will be recovered because of the presence of rainwater in the sump. [HQ--BPOI-NPRC-1994-0007]

3. On February 1, 1994, Lawrence Livermore National Laboratory (LLNL) reported an unmanned aero vehicle (UAV) crash. After $32 \mathrm{~h}$ of flight, the aircraft suddenly appeared to roll and lose response to all ground control and then it crashed within the prescribed test flight area. An incident investigation team was formed under the direction of DOE. [SAN--LLNL-LLNL-1994-0009]

4. On February 1, 1994, another event was reported by LLNL involving unauthorized storage and onsite transpertation of high explosives. To minimize waste, old and abandoned chemicals were moved from the Building 222 complex to the staging area of Building 227 to allow the chemicals to be screened and selected by others for use. The chemicals that did not meet the chemical exchange acceptance criteria were categorized as waste and entered the hazardous waste disposal process.

Assuming that the chemicals to be transported to the Building 612 waste facility were only irritants, a hazardous waste management technician packed 119 containers of chemicals in a 30-gal drum. After checking the chemicals listed on the waste requisition, a hazardous waste chemist approved the transport of the drum to the waste facility. After transfer to the waste facility, the lead lab packer found that two of the items listed were Class A explosives, which the facility is not permitted to accept. (These explosives were later repackaged and moved to a proper location.)

Further review of the chemicals still remaining in Building 227 by the hazardous waste technician identified 12 chemicals that were thought to be potentially explosive. Nine of these were confirmed to be explosive, and operations in the Building 227 staging area were stopped, and the room was secured. Later, the chemicals were moved to an approved building under the guidance of a qualified explosives handler.

Based on the discovery of the explosive chemicals, a site-wide check was made for potential explosives that labs or warehouses might be mishandling. It was determined that no simple procedure exists for identifying uncommon explosives or stating how many references will be used to determine the hazardous properties of chemicals. [SAN--LLNL-LLNL-1994-0008]

Two off-normal occurrences reported this quarter, two which generated significant interest. These two are summarized below.

1. On Jamuary 6, 1994, the Idaho National Engineering Laboratory (INEL) reported a procedure violation. Though past due for a semiannual vehicle preventive maintenance (PM) inspection, INEL'sTest Reactor Area (TRA) Radioactive Liquid Waste Tanker was loaded with radioactive wastewater and shipped to the Idaho Chemical Processing Plant (ICPP), operated by EG\&G, for treatment and disposal. To complete the shipment in a timely manner, a phone call was made to the company's fleet maintenance unit to extend the PM due date. Allowing this shipment to be made included the following violations of the approved transport plan: (1) there are no provisions for extension of service beyond the PM periods; (2) the radiation field at the driver's location was $55 \mathrm{mrem} / \mathrm{h}$, which was above the limit of $26 \mathrm{mrem} / \mathrm{h}$ for a normal shipment; (3) the shipment was not designated a "special shipment" even though the higher exposure rate in the tractor cab would require the shipment to be approved as such; (4) the transport plan was not updated to reflect modifications made to the level-indicator alarms during 1988; 
and (5) the EG\&G fleet services PM checklist had been modified without consideration to or inclusion in the transport plan. As corrective actions, tanker-loading procedures will be revised to include all requirements identified in the approved transport plan, and system engineers will evaluate the level-alarm modifications. [ID-EGG-TRA-1994-0001]

2. Another occurrence, which was repartod by the INEL on February 16, 1994, related to the improper use of a radionctive material package. During a DOE review of the inspection and packaging procedure used to prepere the Model DU (type 20-WC-2A) overpack container (used for iridium shipments), a concern wes raised that the existing facility procedure did not include an adequate visual inspection for corrosion of the wooden overpack body-threaded rods. Upon complete disassembly of the container to check for corrosion, significant and unacceptable damage was discovered. Further, follow-up review of the container's history revealed that though the overpack had been assumed to be of the same configuration as the specification 20-WC-2 overpecks, there were no provisions in 49 CFR for the use of the 20-WC$2 A$ overpack for iridium shipments. The overpacks were removed from use, and use of them is suspendod. [ID-EGG-TRAHC-1994-0001]

Table 1 presents the DOE Program Offices and the number of ORs that were reported to them. (Figure 1 is a graphical representation of this distribution.) Table 2, "Occurrence Report Distribution by DOE Operations Office," is complemented by the bar chart presented in Fig. 2. Table 2 lists the Operations Offices where violations were filod. Note that the "other" category represents violations that originated of fsite of the reporting contractor's facility. Such violations have been separated from the ORs that clearly are the full responsibility of the reporting group and are so identified as "other." This procedure allows cocurrences not to be charged to the reporting Program Office, the Operations Office, or the contractor in these tables or figures, though ORPS has not made a distinction between the reporter and the violator.

The Albuquerque (ALO) and Oak Ridge Operations Offices (ORO) reported the largest number of ORs, with 19 and 7, respectively (Table 2). Only two of ALO's reported ORs were created by "others," whereas three of ORO's ORs were created by "others." Table 3 shows the ORs by contractor organization. Los Alamos National Laboratory (LANL) had the greatest number of ORs by owner, nine; and EG\&G Idaho, Sandia National Laboratory, and Westinghouse Hanford had three cocurrences, respectively. The spread of ORs by the remaining contractors may be seen on Table 3.

The data received from the Shipment Mobility/Accountability Collection (SMAC) summary report of hazardous material shipping activity on May 27, 1994, for the first quarter of 1994 was noted to be incomplete for five reporting contractors. Data for the month of March had not been entered for Sandia National Laboratory, Morgantown Energy, or the Rocky Flats Plant. February and March data were not loaded into the SMAC system for Allied Signal's Kansas City Plant. LANL had a small percentage of radioactive shipments not reported. Because of this lack of reporting, the total number of hazardous materials shipments made by the DOE community is not complete; therefore, no conclusions have been drawn from the information provided.

The Packaging and Transportation Safety (PATS) category for coding packaging and transportation events is presented as Table 4, which shows the classification system and the number of ORs categorized into the codes. About $25 \%$ are occurrences attributed to "others." Shipping papers (5A) is still highest, and contamination (1) is second. Table 5 lists the summary information for the first quarter 1994 reports in the PATS database. 


\section{FUTURE DIRECTION}

This quarterly report was prepared at the same time that the 1993 Annual Report of Packaging-and Transportation-Related Occurrence Reports was under preparation. In future quarterly reports, correlation with the previous-year data and historical records will be used to evaluate the ORs of each quarter more thoroughly.

The use of SMAC data for information purposes will be suspended in future quarterly reports. The consistent lack of complete reporting to SMAC by contractors has led to this decision. For the publication of future annual reports, it is hoped that SMAC will be able to provide complete information to allow analysis of the relationship of the total mumber of shipments and the numbers of occurrences. The SMAC data will be monitored quarterly to identify any uncommon or significant events. 
Table 1. Occurrence report distribution by DOE Program Office

\begin{tabular}{clcc}
\hline & & Description & \multicolumn{2}{c}{ No. of ORs } \\
\cline { 3 - 4 } Code & & 20 & Owner \\
\hline DP & Defense Programs & 7 & 6 \\
EM & Environmental Restoration and Waste Mgt. & 3 & 3 \\
ER & Energy Research & 3 & 0 \\
FE & Fossil Energy & 1 & 0 \\
NE & Nuclear Energy & 3 & 0 \\
& $\quad$ Subtotals & 34 & 9 \\
& & Grand total & 43 \\
\hline
\end{tabular}

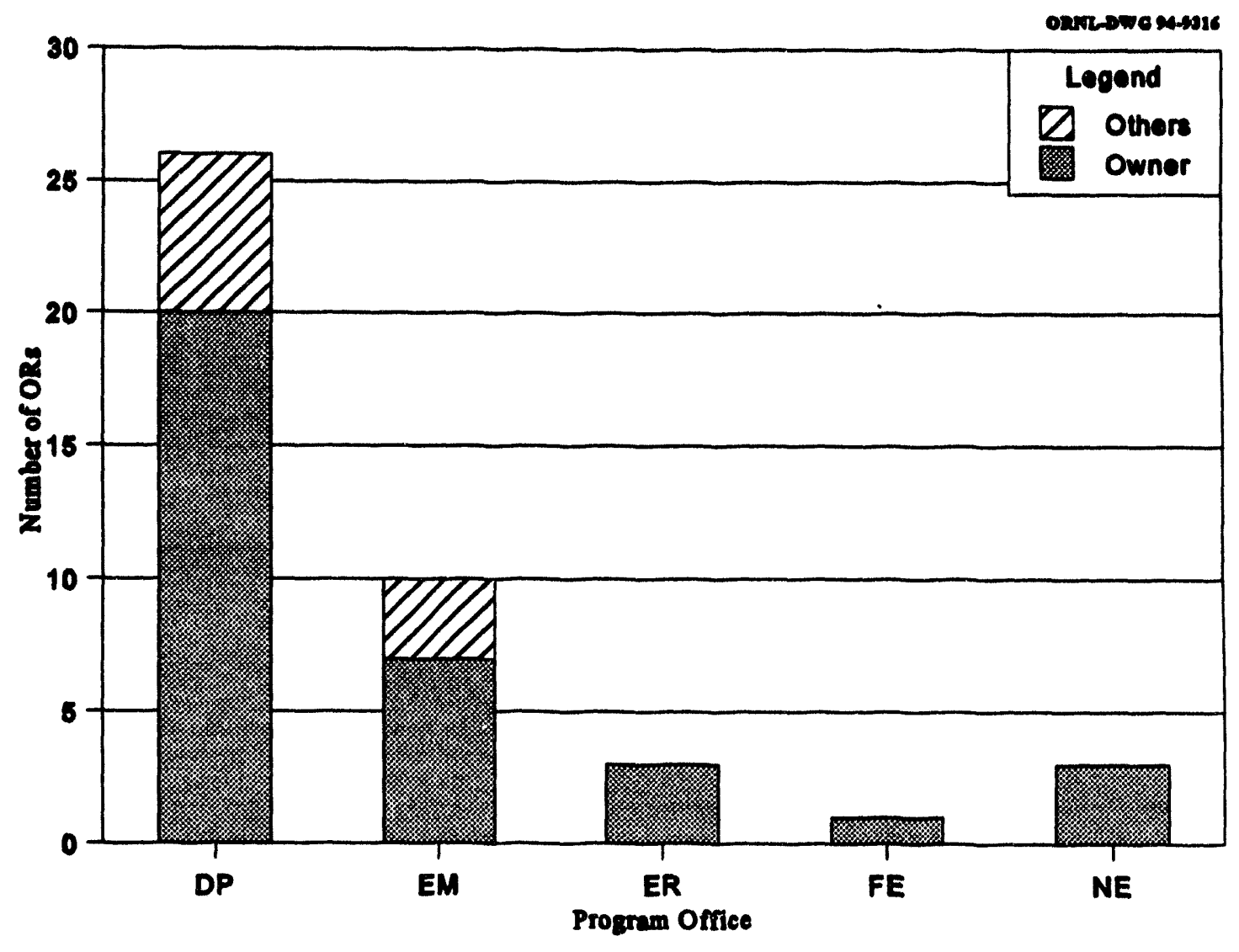

Fig. 1. Occurrence report distribution by DOE Program Office. 
Table 2. Occurrence report distribution by DOE Operations Office

\begin{tabular}{|c|c|c|c|}
\hline \multirow{2}{*}{ Code } & \multirow{2}{*}{ Description } & \multicolumn{2}{|c|}{ No. of ORs } \\
\hline & & Owner & Others \\
\hline ALO & Albuquerque Operations & 17 & 2 \\
\hline $\mathbf{C H}$ & Chicago Operations & 3 & 0 \\
\hline HQ & DOE Headquarters & 1 & 0 \\
\hline ID & Idaho Operations & 3 & 1 \\
\hline NVOO & Nevada Operations & $\mathbf{0}$ & 0 \\
\hline ORO & Oak Ridge Operations & 4 & 3 \\
\hline RFO & Rocky Flats Operations & 0 & 0 \\
\hline $\mathbf{R} \mathbf{L}$ & Richland Operations & 2 & 0 \\
\hline SAN & San Francisco Operations & 3 & 1 \\
\hline \multirow[t]{3}{*}{ SR } & Savannah River Operations & 1 & 2 \\
\hline & Subtotals & 34 & 9 \\
\hline & Grand total & & 43 \\
\hline
\end{tabular}




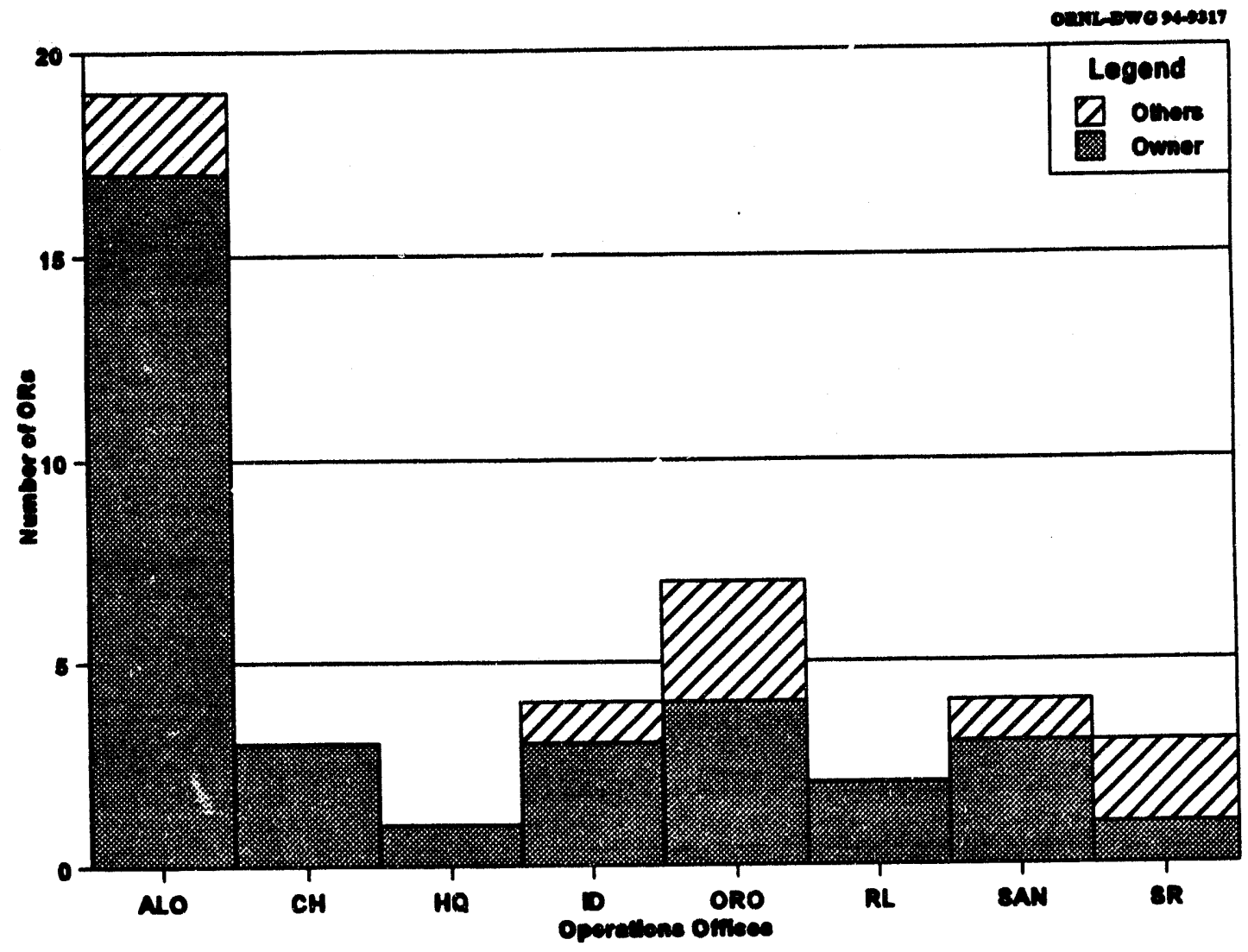

Fig. 2. Occurrence report distribution by DOE Operations Office. 
Table 3. Occurrence report distribution by contractor organizations

\begin{tabular}{|c|c|c|c|}
\hline \multirow{2}{*}{ Code } & \multirow{2}{*}{ Description } & \multicolumn{2}{|c|}{ No. of ORs } \\
\hline & & Owner & Others \\
\hline BNL & Bechtel National, Inc. & 2 & $\mathbf{0}$ \\
\hline BPOI & Bechtel Petroleum Operations, Inc. & 1 & $\mathbf{0}$ \\
\hline EGG & EG\&G Idaho, Inc. & 3 & $\mathbf{0}$ \\
\hline EGGM & EG\&G Mound Applied Technologies & $\mathbf{0}$ & 1 \\
\hline FERM & Fernald Environmental Menagement Project & $\mathbf{0}$ & 2 \\
\hline LANL & Los Alamos National Laboratory & 9 & 1 \\
\hline MHSM & Mason \& Hanger, Silas-Mason Co., Inc. & 1 & 9 \\
\hline MKFO & MK-Ferguson & 2 & 0 \\
\hline MMES & Martin Marietta Energy Systems, Inc. & 2 & 0 \\
\hline MMSC & Martin Marietta Specialty Components & 1 & $\mathbf{0}$ \\
\hline SNL & Sandia National Laboratories & 3 & 0 \\
\hline SU & Stanford University & 1 & $\mathbf{0}$ \\
\hline TSD & Transportation Safeguards Division & 1 & 0 \\
\hline UMTR & Uranium Mill Tailings (UMTRA) Project Office & 1 & $\mathbf{0}$ \\
\hline WHC & Westinghouse Hanford Company & 2 & 0 \\
\hline WSRC & Westinghouse Savannah River Company & 1 & 2 \\
\hline WVNS & West Valley Nuclear Services, Inc. & $\mathbf{0}$ & 1 \\
\hline \multirow[t]{3}{*}{ WWID } & Westinghouse Waste Isolation Division & 1 & 0 \\
\hline & Subtotals & 34 & 9 \\
\hline & Grand total & & 43 \\
\hline
\end{tabular}




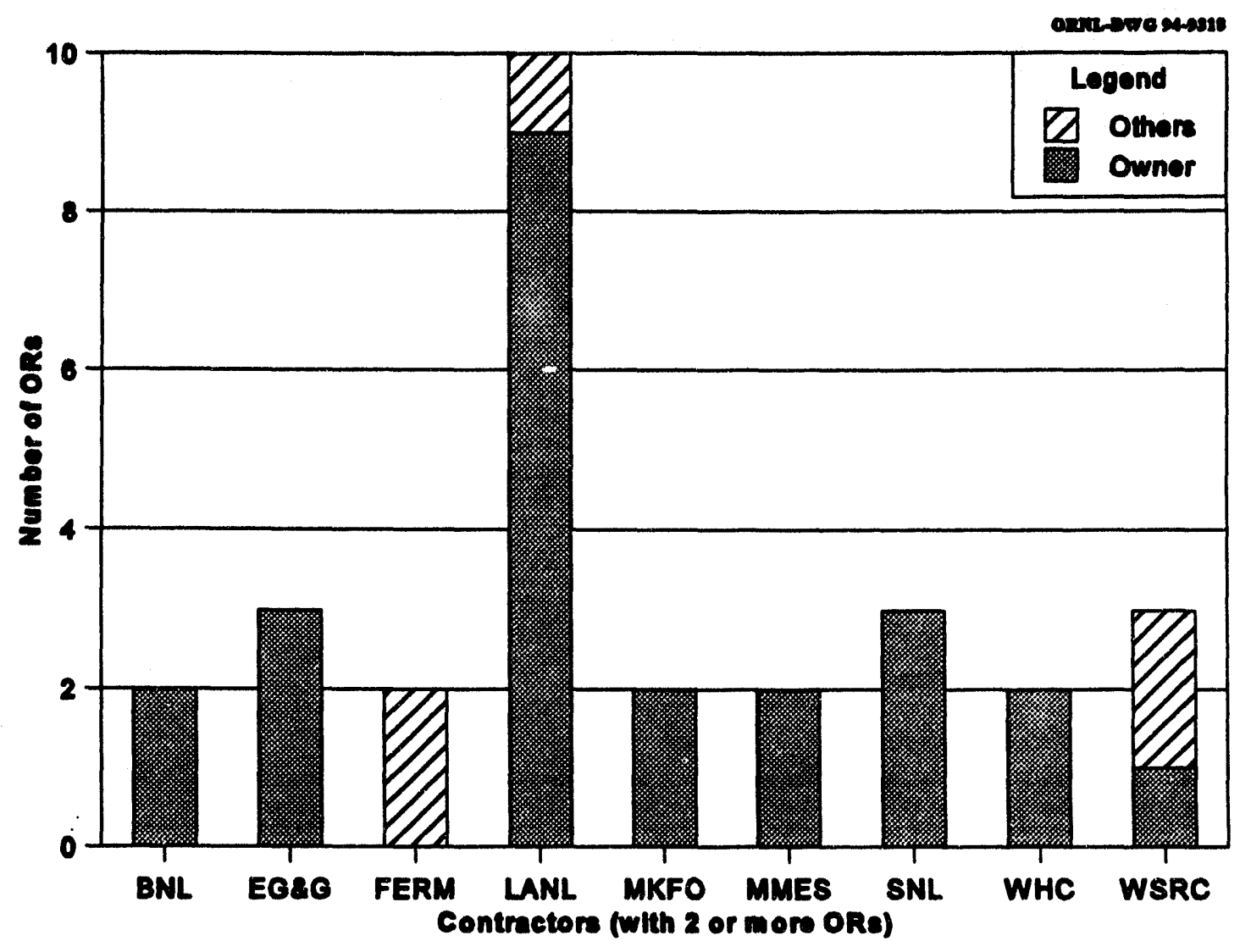

Fig. 3. Occurrence report distribution by contractor organizations. 
Table 4. OR distribution by nature of cocurrences

\begin{tabular}{|c|c|c|}
\hline Code & Description & No. of ORs \\
\hline \multicolumn{2}{|c|}{ 1. Contamination/Release } & 0 \\
\hline \multicolumn{2}{|c|}{ 1A. Radioactive } & 0 \\
\hline \multicolumn{2}{|r|}{ Envirommental } & $\mathbf{0}$ \\
\hline $1 \mathrm{~A} 2$. & Personnel & $\mathbf{0}$ \\
\hline $1 \mathrm{~A} 3$. & Equipment & 4 \\
\hline 1B. $I$ & Hazardous Materials & $\mathbf{0}$ \\
\hline $1 \mathrm{B1}$ & Environmental & 2 \\
\hline $1 B 2$. & Personnel & 2 \\
\hline \multirow[t]{2}{*}{$1 B 3}$. & Equipment & 0 \\
\hline & Totals & 8 \\
\hline
\end{tabular}

2. Packaging

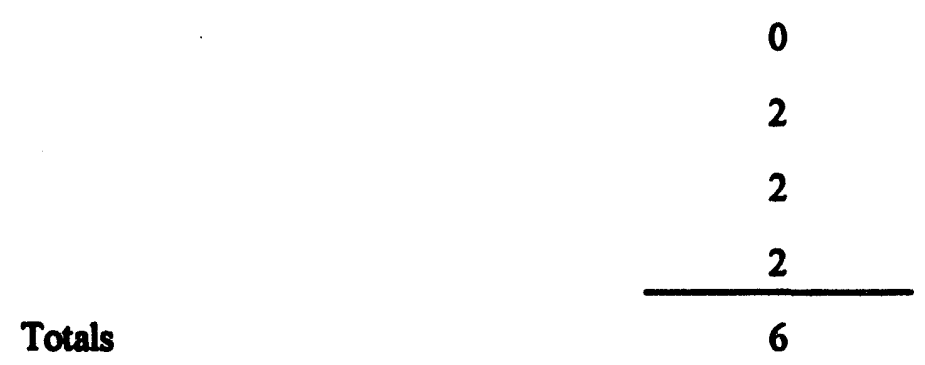

3. Storage Incident to Transport

$\frac{0}{0}$

4. Quality Assurance

Totals

$\frac{0}{0}$


Table 4. (continued)

\begin{tabular}{|c|c|c|}
\hline Code & Description & No. of ORs \\
\hline \multicolumn{2}{|c|}{ 5. Shipment Preparation } & 3 \\
\hline $5 \mathrm{~A}$. & Shipping Papers & 5 \\
\hline 5B. & Marking & 0 \\
\hline sc. & Labeling & 2 \\
\hline 5D. & Loading and Tie-downs & 0 \\
\hline \multirow[t]{2}{*}{ SE. } & Placeards & 0 \\
\hline & Totals & 10 \\
\hline \multicolumn{2}{|c|}{ 6. Modal Safety } & 0 \\
\hline $6 \mathrm{~A}$. & Motor or Driver Safety & 5 \\
\hline 6B. & Aircraft Safety & 1 \\
\hline 6C. & Rail Safety & 0 \\
\hline 6D. & Barge Safety & 0 \\
\hline \multirow[t]{2}{*}{$6 \mathrm{E}$} & Pipeline & 0 \\
\hline & Totals & 6 \\
\hline \multicolumn{2}{|c|}{ 7. Operations } & 2 \\
\hline 7A. & Lack of Procedures & 1 \\
\hline $7 \mathrm{~B}$. & Training & 0 \\
\hline $7 c$. & Supervision & 0 \\
\hline \multirow[t]{2}{*}{$7 \mathrm{D}}$. & Disregard of Procedures & 1 \\
\hline & Totals & 4 \\
\hline
\end{tabular}


Table 4. (continued)

\begin{tabular}{|c|c|c|}
\hline Code & Description & No. of ORs \\
\hline \multicolumn{2}{|c|}{ 8. Occurrence Created by Others (non-DOE or DOE/Contractor) } & $\mathbf{0}$ \\
\hline 8A. & Shipping Preparation & 5 \\
\hline 8B. & Packaging & $\mathbf{0}$ \\
\hline 8C. & Quality Assurance & $\mathbf{0}$ \\
\hline 8D. & Vehicle or Driver Safety & 2 \\
\hline 8E. & Contamination & 1 \\
\hline \multirow[t]{3}{*}{$8 F$. } & NOS & 1 \\
\hline & Totals & 9 \\
\hline & Grand total & 43 \\
\hline
\end{tabular}




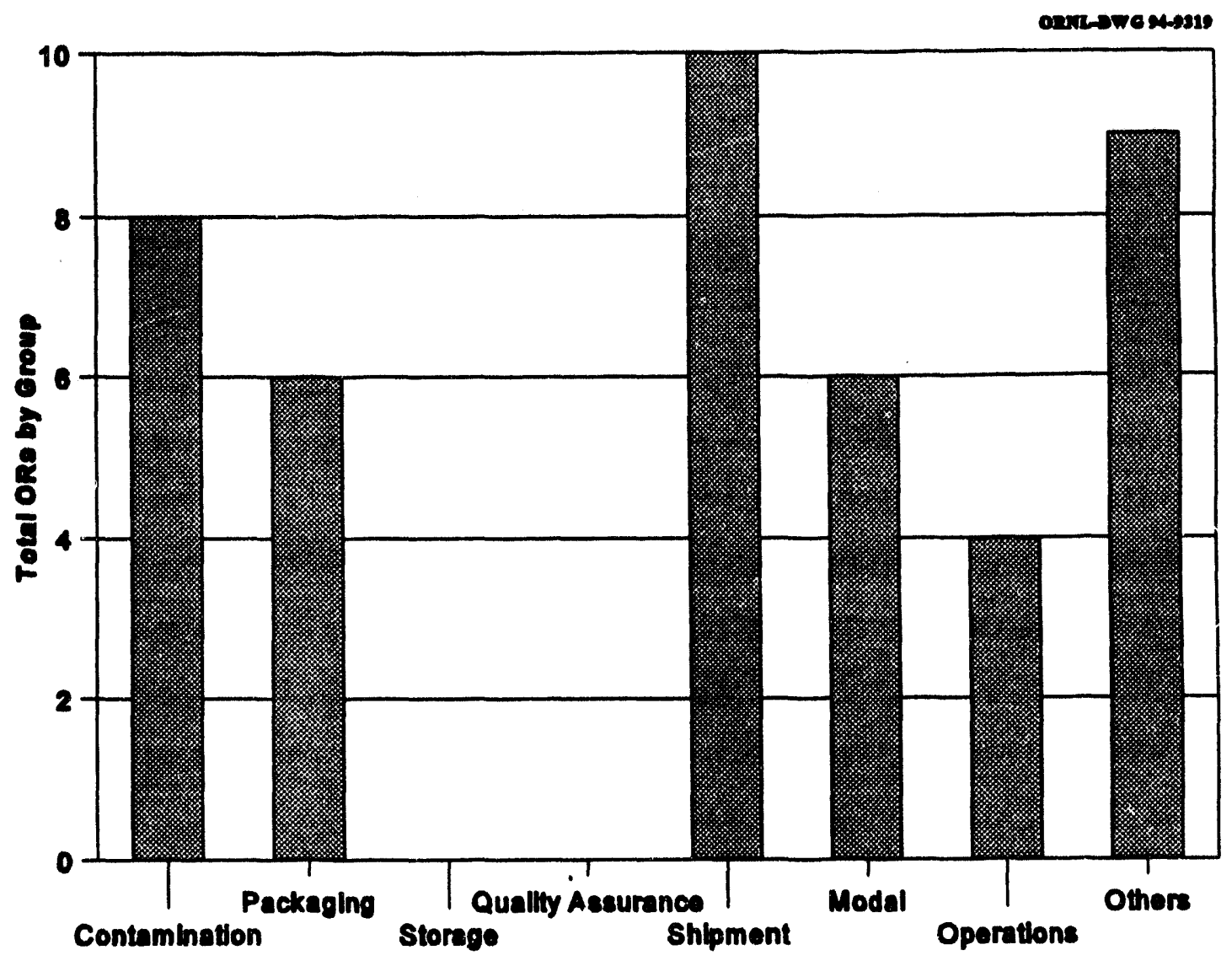

Fig. 4. Nature of Occurrence. 
Table 5. Occurrences reported in Weekly Reports for the first quarter 1994

\begin{tabular}{|c|c|c|}
\hline ORPS report number & $\begin{array}{c}\text { PATS nature of } \\
\text { occurrence }\end{array}$ & $\begin{array}{l}\text { Weekly issue } \\
\text { number }\end{array}$ \\
\hline ALO--TSD-TSS-1994-0001 & $7 A$ & OR-94-09 \\
\hline ALO-UMTR-UMTRA-1994-0002 & $1 B 2$ & OR-94-13 \\
\hline ALO-WWID-WIPP-1994-0002 & 2B & OR-94-08 \\
\hline ALO-AO-MHSM-PANTEX-1994-0028 & $5 \mathrm{C}$ & OR-94-12 \\
\hline ALO-DA-EGGM-EGGMAT04-1994-0002 & 8D & OR-94-09 \\
\hline ALO-KO-SNL-2000TTR-1994-0001 & $6 \mathrm{~A}$ & OR-94-06 \\
\hline ALO-KO-SNL-7000-1994-0002 & $6 A$ & OR-94-10 \\
\hline ALO-KO-SNL-NMSEC-1994-0002 & $6 A$ & OR-94-07 \\
\hline ALO-LA-LANL_ACCCOMPLEX-1994-0002 & $1 B 2$ & OR-94-13 \\
\hline ALO-LA-LANL_CHEMLASER-1994-0001 & sC & OR-94-13 \\
\hline ALO-LA-LANL-ESHSUPT-1994-0001 & 5 & OR-94-04 \\
\hline ALO-LA-LANL-FIRNGHELAB-1994-0001 & 5 & OR-94-04 \\
\hline ALO-LA-LANL-MATSCCMPLX-1994-0002 & 5 & OR-94-09 \\
\hline ALO-LA-LANL-MATWAREHS-1993-0031 & $8 A$ & OR-94-02 \\
\hline ALO-LA-LANL-PHYSCOMPLX-1994-0002 & $5 A$ & OR-94-07 \\
\hline ALO-LA-LANL-PHYSTECH-1994-0003 & $6 A$ & OR-94-05 \\
\hline ALO-LA-LANL-SIGMA-1994-0003 & $5 A$ & OR-94-05 \\
\hline ALO-I A-LANL-TA55-1994-0004 & $5 A$ & OR-94-06 \\
\hline ALO-PI-MMSC-PINELLAS-1994-0004 & 7 & OR-94-08 \\
\hline CH-AMES-AMES-1994-0002 & $5 A$ & OR-94-12 \\
\hline CH-BH-BNL-PE-1994-0002 & $1 \mathrm{A3}$ & OR-94-07 \\
\hline CH-BH-BNL-PE-1994-0003 & 1B1 & OR-94-08 \\
\hline HQ-BPOI-NPRC-1994-0007 & 1B1 & OR-94-08 \\
\hline ID-EGG-TRA-1994-0001 & $7 D$ & OR-94-03 \\
\hline ID-EGG-TRAHC-1993-0012 & $2 \mathrm{C}$ & OR-94-01 \\
\hline ID-EGG-TRAHC-1994-0001 & $2 \mathrm{C}$ & OR-94-09 \\
\hline ID-WVNS-EOT-1993-0009 & $8 A$ & OǨ-94-05 \\
\hline
\end{tabular}


Table 5. (continued)

\begin{tabular}{lll}
\hline \multicolumn{1}{c}{ ORPS report number } & $\begin{array}{c}\text { PATS nature of } \\
\text { cccurrence }\end{array}$ & $\begin{array}{c}\text { Weckly issue } \\
\text { number }\end{array}$ \\
\hline ORO-FERM-FEMP-1994-0005 & 8 & OR-94-05 \\
ORO-FERM-FEMP-1994-0009 & $8 \mathrm{~A}$ & OR-94-07 \\
ORO-MKFO-Y12CENTENG-1993-0021 & $1 \mathrm{A3}$ & OR-94-06 \\
ORO-MKFO-Y12CENTENG-1993-0026 & $2 \mathrm{~A}$ & OR-94-02 \\
ORO-MMES-PGDPENVRES-1994-0003 & $6 \mathrm{~A}$ & OR-94-13 \\
ORO-MMES-Y12DEFPGM-1994-0002 & $1 \mathrm{A3}$ & OR-94-03 \\
ORO-MMES-Y12DEFPGM-1994-0007 & $8 \mathrm{~A}$ & OR-94-12 \\
RL-WHC-TANKFARM-1994-0011 & $2 \mathrm{~B}$ & OR-94-11 \\
RL-WHC-TPLANT-1994-0002 & $2 \mathrm{~A}$ & OR-94-06 \\
SAN-LLNL-LLNL-1994-0008 & 7 & OR-94-07 \\
SAN-LLNL-LLNL-1994-0009 & OB & OR-94-07 \\
SAN-LLNL-LLNL-1994-0022 & $8 \mathrm{~F}$ & OR-94-13 \\
SAN-SU-SLAC-1994-0003 & SA & OR-94-12 \\
SR-WSRC-ESH-1994-0001 & OR-94-03 \\
SR-WSRC-RMAT-1994-0006 & OR-94-13 \\
SR--WSRC-TD-1994-0001 & OR-94-11 \\
\hline
\end{tabular}




\section{INTERNAL DISTRIBUTION}

1. C. J. Armstrong

2. J. M. Begovich

3. R. G. Bugos

4. A. G. Crofif

5. L. S. Dickerson

6. K. F. Bekermm

7. R. M. Gove

8. R. F. Holdaway

9. S. D. Jermings

10. L. E. MoNecese

11. C. V. Parte

12. R. B. Pope

13. R R Rawl

14. D. E. Reichle
15. P. S. Rohwer

16. L. B. Shappert

17. R.M. Walker

18. M. J. Welch

19. B. W. Welles

20. D. L. Williams, Jr.

21. S. J. Wolfo

22. Central Research Library

23. Document Reference Section

24. Laboratory Reconds-RC

25-26. Laboratory Records Department

27. Laboratory Protection Division

28. ORNL Patent Section

29 ORNL Public Relations Office

\section{EXTERNAL DISTRIBUTION}

30. R. W. Berber, Director, Office of Risk Analysis and Technology, U.S. Department of Energy, EH-33, Washington, D.C. 20585.

31. M. L. Bennett, DOE-OR, P.O. Box 2001, Oak Ridge, TN 37831.

32. L. G. Blalock, Director, Transportation Management Division, U.S. Department of Energy, EM-261, Washington, D.C. 20585.

33. C. E. Collier, E. R. Johnson Associates, Inc., 20251 Century Blvd., Germantown, MD 20874.

34. A. Kepoor, Transportation and Packaging Safety Division, U.S. Department of Energy, EH-332, Washington, D.C. 20585.

35. B. Lester, DOE-OR, P.O. Box 2001, Oak Ridge, TN 37831.

36-61. T. S. Necdels, Transportation and Packaging Safety Division, U.S. Department of Energy, EH-332, Washington, D.C. 20585.

6?-63. Office of Scientific and Technical Information, P.O. Box 62, Oak Ridge, TN 37831.

64. J. Schuler, Transportation and Packaging Safety Division, U.S. Department of Energy, EH-332, Washington, D.C. 20585.

65. D. Stancell, DOE-OR, P.O. Box 2001, Oak Ridge, TN 37831.

66. M. E. Wangler, Director, Transportation and Peckaging Safety Division, U.S. Department of Energy, EH-332, Washington, D.C. 20585. 
67. D. Williford, DOE-OR, P.O. Box 2001, Oak Ridge, TN 37831.

68. Assistant Manager of Energy Research and Development, P.O. Box 2008, Oak Ridge, TN 37831-62.69. 

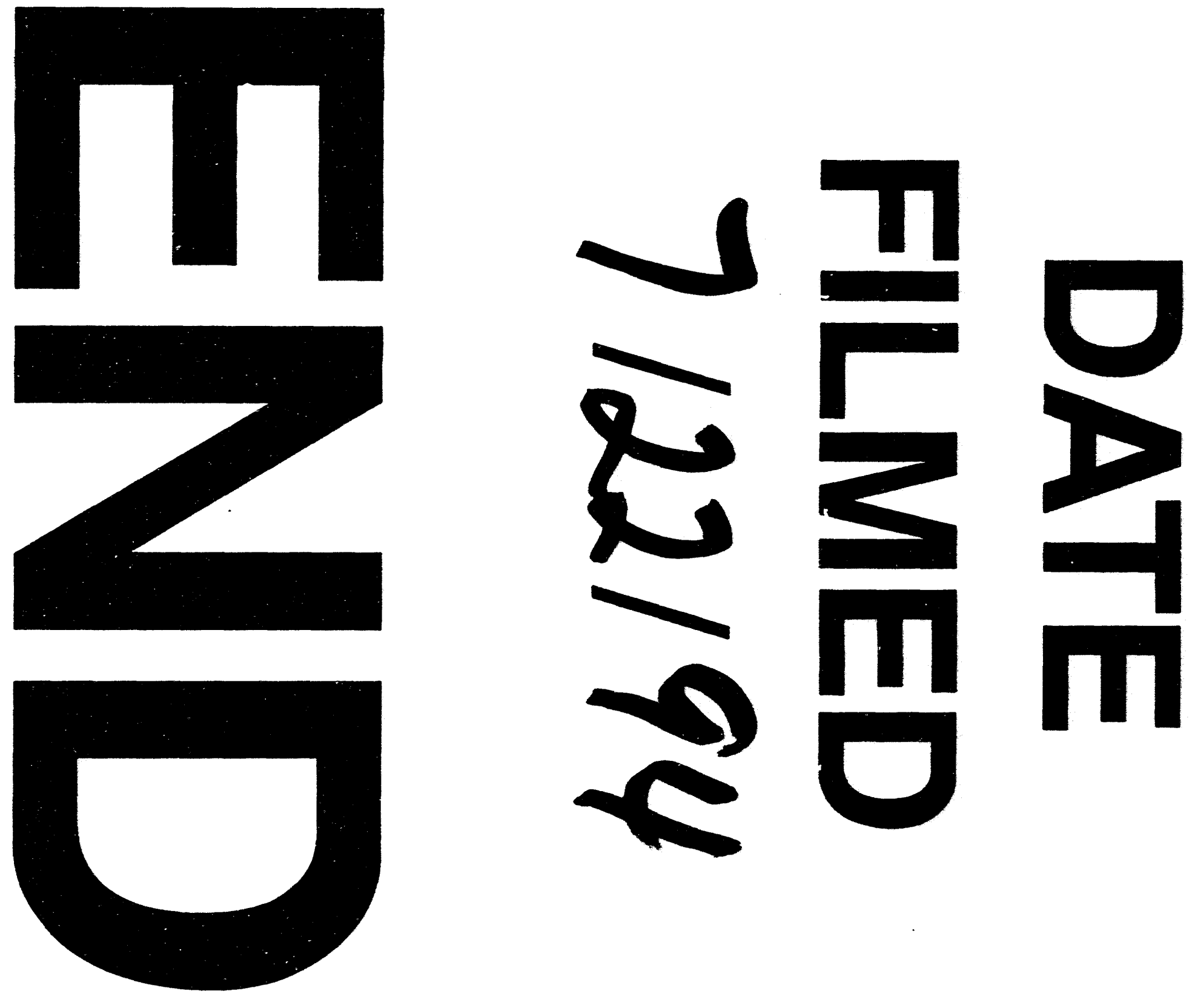
